J. Clin. Chem. Clin. Biochem.

Vol. 25, 1987, pp. 53-59

(C) 1987 Walter de Gruyter \& Co.

Berlin - New York

\title{
Multi-Centre Study of a New CEA Enzyme Immunoassay Using Monoclonal Antibodies
}

By J. Spona

Division of Molecular Endocrinology, First Department of Obstetrics and Gynaecology, University of Vienna, Austria

Anne-C. Kessler and R. Deeg

Boehringer Mannheim GmbH, Biochemical Research Centre, Tutzing, FRG

and collaborative study group:

K. D. Bagshawe, Charing Cross Hospital, London

W. Ehrenthal, Universitätsklinik, Mainz

L. Jacobssen, Regionsjukhuset, Umeå

G. J. van Kamp, Academisch Ziekenhuis der Vrije Universiteit, Amsterdam

$S$. von Kleist, Institut für Immunologie der Universität, Freiburg

R. Masseyeff, V.E.R. de Medicine, Nice

J. Ohkawa, Kyogo Medical Centre, Osaka

R. Pfeiffer, Universitätsklinikum, Essen

A. Pinchera, Istituto di Metodologia Clinica, Pisa

S. Soarnil, R.S. Virgen del Lluch, Palma de Mallorca

R. Schmidt, Klinikum Mannheim

L. Thienpont, Farmaceutisch Instituut, Gent

W. Riesen, Institut für Tumorforschung, Bern

D. Kutter, Laboratoire Luxemburg

(Received July 19, 1985/August 4, 1986)

Dedicated to Professor Dr. E. Kaiser on the occasion of his 60th birthday

Summary: The use of a new monoclonal enzyme immunoassay (EIA) for the carcinoembryonic antigen * (CEA) (Enzymun-Test ${ }^{\circledR}$ CEA) was evaluated in a multi-centre study. Fifteen different laboratories participated in the study. Data from the investigation were analysed in terms of precision, sensitivity, specificity and correlation with other test methods. The intra-assay coefficient of variation was between $1.3 \%$ at $23.0 \mu \mathrm{g} / 1$ CEA and $13.9 \%$ at $1.3 \mu \mathrm{g} / \mathrm{l} \mathrm{CEA}$. Inter-assay reproducibility ranged from $3.6 \%$ to $19.2 \%$. The apparent sensitivity of the new EIA for CEA was approx. $0.5 \mu \mathrm{g} / \mathrm{l}$ CEA. The findings indicate that lipaemic and haemolytic sera and samples taken from icteric, rheumatic and dialysis patients did not have any influence on the results. There was no evidence that drugs commonly used in the treatment of carcinoma patients have any influence on the assay results. A good correlation between the new EIA for CEA and six other CEA enzyme immunoassay or radioimmunoassay methods was registered. These results seem to be of significance in particular for the monitoring of therapy for carcinoma patients. The new EIA for CEA exhibits a high degree of sensitivity, specificity and reproducibility. 


\section{Introduction}

Carcinoembryonic antigen (CEA) is a glycoprotein consisting of a polypeptide chain with a molecular weight of $180 \mathrm{kD}$. It has a carbohydrate content of 40 to $60 \%$. The protein moiety of CEA is a single polypeptide chain with multiple intrachain disulphide bonds. The pure peptide chain consists of some 800 amino acids (1). The physiological function of CEA is not known.

CEA is normally detectable only in very low concentrations in the serum of healthy men and women. Pathologically raised CEA serum levels are encountered in conjunction with CEA-producing tumours. CEA has been used for monitoring patients with colorectal carcinoma, and its role as a tumour marker and as diagnostic tool in this disease is well documented (2). Recent reports suggest that CEA may also be used as a tumour marker for cancers other than colorectal (3). It was also noted to be of use in gynaecological tumours (4-6).

Since the first report of a radioimmunoassay system (7), other radioimmunological methods, in addition to enzyme immunoassay systems, have been described. Some studies show a strong correlation between different assay systems $(8,9,10)$, others $(11$, 12) reveal a low-degree of correlation or even lack of comparability.

The aim of this multi-centre study was to investigate the sensitivity, the specificity and reproducibility of a new CEA enzyme immunoassay (EIA) using monoclonal antibodies (Enzymun-Test ${ }^{\circledR}$ CEA). In addition, the investigation was aimed at comparing CEA serum levels estimated by this new EIA with other enzyme immunoassay and radioimmunoassay methods.

This multi-centre form of organization was used to ascertain whether data obtained with this new EIA is comparable with results obtained by other assay systems. We were prompted to investigate this question, since patients in whom serial CEA determinations are indicated are not necessarily investigated by the same laboratory. Another aim of the multi-centre study was to define reference ranges, to describe CEA serum levels in various malignancies and to evaluate whether this new CEA EIA method can be used for monitoring carcinoma patients.

\section{Materials and Methods \\ Immunoassay technology}

The assay is based on the sandwich EIA principle using solid phase and enzyme-labelled monoclonal antibodies (13).

\section{Reagents}

Test kit "Enzymun-Test ${ }^{\circledR}$ CEA", cat. no: 204501, from Boehringer Mannheim, D-6800 Mannheim, containing incubation buffer $100 \mathrm{mmol} / 1$ acetate buffer, pH 5.7, anti-CEA-peroxidase-conjugate $>100 \mathrm{U} / \mathrm{l}$; substrate buffer $100 \mathrm{mmol} / 1$ phosphate-citrate-buffer, $\mathrm{pH} 4.4 ; 3.2 \mathrm{mmol} / 1$ sodium perborate, 1.9 mmol/1 di-ammonium 2.2'-azino-bis (3-ethylbenzothiazoline-6sulphonate) (ABTS ${ }^{\circledR}$ ); 5 standards CEA in horse serum, concentration $0-55 \mu \mathrm{g} / \mathrm{l}$; control serum, CEA in horse serum; 100 plastic vials coated with CEA antibody, binding capacity $>200$ ng CEA per vial. The working solution is prepared according to the manufacturer's instructions.

\section{Assay protocol}

1. Samples or standards $(100 \mu \mathrm{l})$ were incubated with $1 \mathrm{ml}$ antiCEA-conjugate solution in the plastic tubes for 2 hours at $20-25^{\circ} \mathrm{C}$.

2. Vial contents were aspirated and plastic tubes were rinsed three times with tap water.

3. ABTS $^{\circledR}$ substrate solution $(1 \mathrm{ml})$ was added and incubation continued for another 60 minutes at $20-25^{\circ} \mathrm{C}$.

4. Absorbance was read at $405 \mathrm{~nm}$ and CEA concentrations were calculated from the calibration curve.

\section{Standard calibration}

The working standards of the test kit were prepared in horse serum. They were calibrated against the first international reference preparation of CEA (14) of the National Institute for Biological Standards and Control, Holly Hill, Hampstead, London, NW3 6RB.

\section{Antigen preparation}

CEA was purified from an adeno-carcinoma of the colon, according to the method of Krupey et al. (15) modified as described by Krantz et al. (16). The purity of the CEA preparation was greater than $90 \%$ as judged by analytical polyacrylamide gel electrophoresis.

\section{Monoclonal antibody production}

\section{Immunization}

The procedure of Accolla et al. (17) was used. Balb/c mice were immunized twice with $15 \mathrm{ng}$ purified CEA in complete Freund's adjuvant per injection in intervals of 14 weeks. One day after the second injection the mice were immunized with $100 \mu \mathrm{g}$ CEA in saline intraperitoneally. The following day the mice received a final booster dose of $150 \mu \mathrm{g}$ CEA in saline intraperitoneally. Three days later the spleen cells were fused.

\section{Fusion}

Spleen cells of immunized Balb/c mice were fused with mouse myeloma cells P3-NS1/1-AG4 using polyethylene glycol (PEG) 4000 (volume fraction 0.40 ). The resulting cell suspension was distributed in the wells of five-96-well-plates. The culture supernatants were screened for CEA antibody production.

The positive cultures were cloned by cytofluorographic separation into five 96-well plates per positive well of the primary culture. The cells of a positive hybridoma clone were injected, $5 \times 10^{6}$ cells, into a pristan-primed Balb/c mouse for ascites induction. 


\section{Purification of immunoglobulins}

The immunoglobulins were separated from albumin and other body fluid proteins by three-fold ammonium sulphate fractionation and subsequent DEAE cellulose chromatography.

\section{Characterization of the antibodies}

The antibodies Tu 2 and 3 used in the test kit, were analysed by isoelectrofocusing, immunoglobulin sub-class determination and competitive RIA. Both belong to the IgG sub-class IgG $1 / K$. Tu 2 has an affinity constant $K_{a}$ of $2.5 \times 10^{10}$, Tu 3 of $1 \times 10^{10}$ as measured in $0.02 \mathrm{~mol} / 1$ Tris buffer according to Steward \& Petty (18). The reactivity with non-specific crossreacting antigen (NCA) (19) is less than $0.05 \%$ for Tu 2 and less than $0.005 \%$ for Tu 3 . Granulocytes do not react with either antibody.

\section{Evaluation procedure}

Enzymun-Test ${ }^{\circledR}$ CEA was assayed in 15 laboratories. All serum samples were determined in duplicate.

Four laboratories followed the manual test procedure, 11 laboratories were equipped with Enzymun-Test ${ }^{\circledR}$ System ES 22 (20), a modular batch analyser system (ES 22, Boehringer Mannheim GmbH).

Besides one self-developed CEA radioimmunoassay the following kits were used:

RIA-gnost ${ }^{\circledR}$ CEA, Behringwerke AG; CEA EIA Test, Roche; Abbott CEA-EIA polyclonal and

Abbott CEA monoclonal, Abbott laboratories; Phadebas CEA PRIST $^{\circledR}$ radioimmunoassay, Pharmacia GmbH.

For the interassay precision, Lyphochek ${ }^{\circledR}$ Immunoassay control serum (human) levels I (A), II (B), III (C), BIO-RAD ECS Division, and the control serum of Enzymun-Test ${ }^{\circledR}$ CEA (D) were used.

\section{Results}

\section{Precision}

The intra-assay precision deterrmined in human sera with concentrations of up to $30.3 \mu \mathrm{g} / \mathrm{l}$ CEA is shown in figure 1 . The coefficients of variation ranged from $1.3 \%$ at $23.0 \mu \mathrm{g} / \mathrm{l} \mathrm{CEA}$ to $13.9 \%$ at $1.3 \mu \mathrm{g} / \mathrm{l} \mathrm{CEA}$.

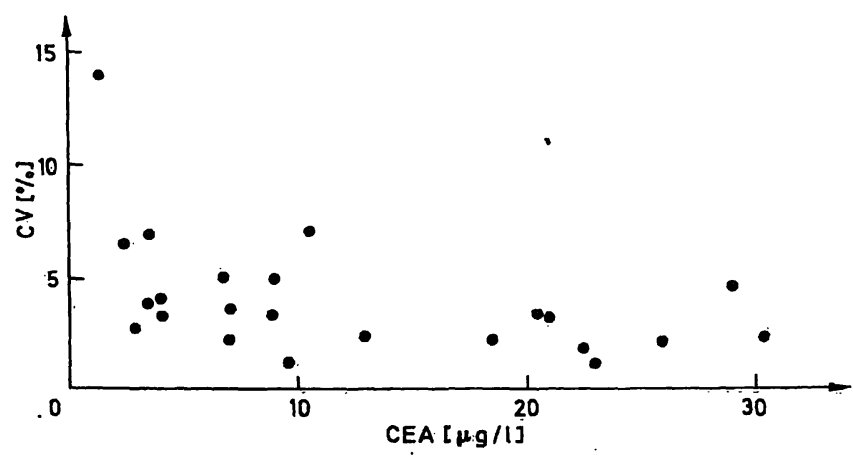

Fig. 1. Intra-assay precision in CEA concentration from 1.3$30.3 \mu \mathrm{g} / 1$. The results of all laboratories are summarized in mean values $\pm 2 S D(n=10)$.
The inter-assay reproducibility was determined by 15 participants from duplicate measurements of 4 commercial control sera over ten days. The overall interassay coefficients of variation ranged from 3.6$19.2 \%$ (tab. 1).

Tab. 1. Inter-assay precision from control sera. Mean $(\overline{\mathbf{x}})$ of all means with the standard deviation (SD) and the coefficient of variation (CV) of $n$ experiments collected from all laboratories.

\begin{tabular}{lclr}
\hline Sample & $\begin{array}{l}\overline{\mathrm{x}} \\
{[\mu \mathrm{g} / \mathrm{l}]}\end{array}$ & $\begin{array}{l}\text { SD } \\
{[\mu \mathrm{g} / \mathrm{l}]}\end{array}$ & $\begin{array}{l}\mathrm{CV} \\
{[\%]}\end{array}$ \\
\hline Control A & 2.6 & 0.48 & 18.5 \\
Control B & 14.1 & 0.59 & 4.2 \\
Control C & 21.5 & 1.05 & 4.9 \\
Control D & 8.3 & 0.30 & 3.6 \\
\hline
\end{tabular}

\section{Linearity and influence of diluent}

A patient specimen containing $41 \mu \mathrm{g} / \mathrm{l}$ CEA was diluted with increasing amounts of CEA-free human serum and the zero standard (horse serum) of the kit. A linear regression was obtained with both diluents (fig. 2).

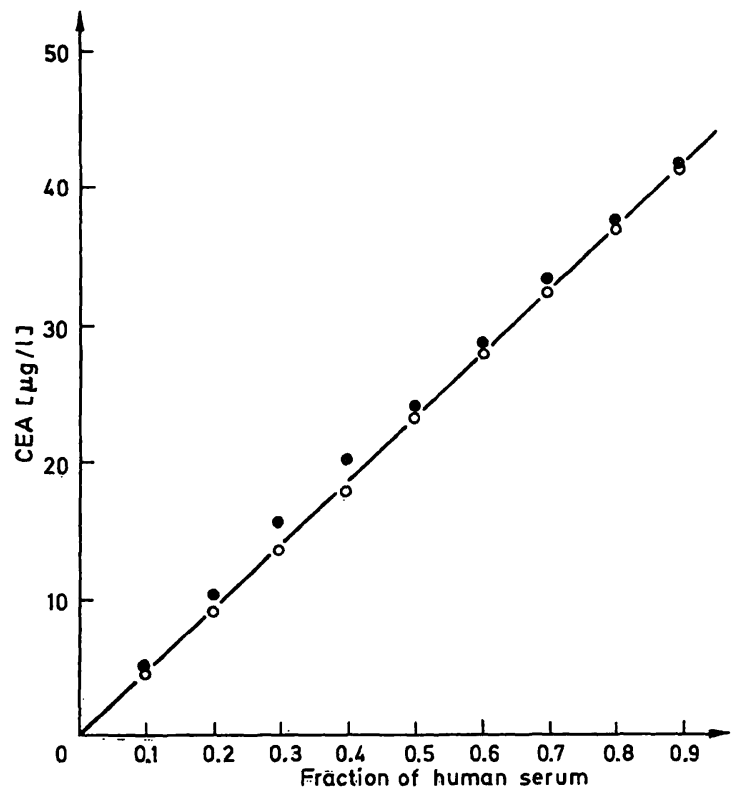

Fig. 2. Dilution of a human serum with: $0 \rightarrow 0$ CEA-free standard of the kit - - CEA-free human serum

\section{Potential sensitivity}

To determine the lowest concentration of CEA statistically distinguishable from CEA-free specimens, the zero standard of the kit was assayed in single measurements $(n=20)$. The detection limit of CEA is defined as the three-fold standard deviation of absorbance of zero standard calculated from the standard curve. A sensitivity of less than $0.5 \mu \mathrm{g} / \mathrm{l} \mathrm{CEA}$ was noted (fig. 3). 


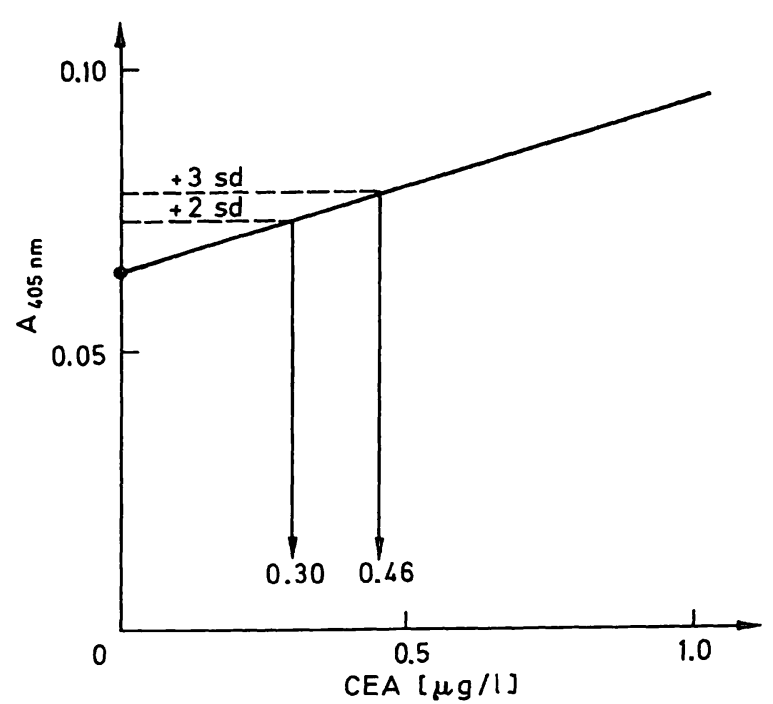

Fig. 3. Sensitivity of the assay. The threefold standard deviation from the zero standard absorbance $(n=20)$ was calculated in $\mu \mathrm{g} / \mathrm{l} \mathrm{CEA}$.

\section{Recovery}

The recovery was assayed in spiked human sera. Equal amounts of a solution of purified CEA (58 $\mu \mathrm{g} / \mathrm{l})$ and human sera containing $0-5.47 \mu \mathrm{g} / 1$ CEA were mixed. The recovery values obtained ranged from 88 to $106 \%$ (tab. 2).

Tab. 2. Recovery study using serum samples diluted $1+1$ (by vol.) with a solution of purified CEA $(58 \mu \mathrm{g} / \mathrm{l})$.

\begin{tabular}{rllc}
\hline Sample & $\begin{array}{l}\text { Serum } \\
\text { CEA } \\
{[\mu \mathrm{g} / 1]}\end{array}$ & $\begin{array}{l}\text { Measured } \\
\text { CEA } \\
{[\mu \mathrm{g} / 1]}\end{array}$ & $\begin{array}{c}\text { Recovery } \\
{[\%]}\end{array}$ \\
\hline 1 & \pm 0 & 27.85 & 96 \\
2 & 0.44 & 29.67 & 101 \\
3 & 1.68 & 30.01 & 101 \\
4 & 1.71 & 31.64 & 106 \\
5 & 1.78 & 29.12 & 97 \\
6 & 2.08 & 30.62 & 102 \\
7 & 2.42 & 30.76 & 102 \\
8 & 4.83 & 29.74 & 94 \\
9 & 5.00 & 28.96 & 91 \\
10 & 5.47 & 28.18 & 88 \\
\hline
\end{tabular}

\section{Specificity}

Icteric, lipaemic, haemolytic sera and specimens from patients suffering from rheumatic diseases and dialysed patients were diluted with normal human serum and then spiked with CEA. The recovery of CEA ranged from 94 to $104 \%$. These results were similar to those obtained in the recovery study (tab. 2). No interference by bilirubin $(428 \mu \mathrm{mol} / \mathrm{l})$, lipids (triacylglycerol concentration $10.26 \mathrm{mmol} / \mathrm{l}$ ) haemoglobin $(1 \mathrm{~g} / 1)$, rheumatic factors or by dialysis could be observed.

The influence of drugs was assayed for the 37 effective components most frequently used (21) as well as Diethylstilbestrol, Cisplatin, Doxorubicin, Etoposid, Fluorouracil, Aminoglutethimid, Tamoxifen and Ifosfamid. Normal serum was spiked with CEA and with these substances. None of the drugs affected the reproducibility or accuracy of the assay.

\section{Correlation studies}

Table 3 shows a comparison of the results obtained by Enzymun-Test ${ }^{\circledR}$ CEA and by 5 other CEA assays. Regression parameters are calculated using a biometric regression procedure in accordance with Passing \& Bablok (22). A good correlation was observed for the enzyme immunoassays and the self-developed radioimmunoassay, except for the results of laboratory 8 (low CEA values). Laboratories 7 and 9 did not collect enough data for statistical evaluation; laboratories 6,11 and 12 did not take part in the correlation trial. Two examples of grapphical correlations are demonstrated in figures 4 and 5.

\section{Distribution of CEA values}

CEA values were determined in a group of 541 healthy control subjects (tab. 4) as well as in 590 patients with confirmed carcinoma and in 146 patients with non-malignant diseases (tab. 5). No

Tab. 3. Correlation between Enzymun-Test ${ }^{\circledR}$ CEA (x) and 6 different EIA and RIA kits $(y)$ using a biometric regression procedure.

\begin{tabular}{|c|c|c|c|c|c|c|c|c|}
\hline \multirow{2}{*}{$\begin{array}{l}\text { Lab- } \\
\text { ora- } \\
\text { tory }\end{array}$} & \multicolumn{2}{|l|}{ Method } & \multirow[t]{2}{*}{$\mathbf{N}$} & \multirow{2}{*}{$\begin{array}{l}\text { Slope } \\
\text { b }\end{array}$} & \multirow{2}{*}{$\begin{array}{l}\text { Intercept } \\
\mathrm{a}\end{array}$} & \multirow{2}{*}{$\begin{array}{l}\text { CEA } \\
\overrightarrow{\mathrm{x}} \\
{[\mu \mathrm{g} / 1]}\end{array}$} & \multirow{2}{*}{$\begin{array}{l}\text { CEA } \\
\bar{y} \\
{[\mu \mathrm{g} / 1]}\end{array}$} & \multirow[t]{2}{*}{$\cdot \mathbf{I}$} \\
\hline & $\mathbf{x}$ & y & & & & & & \\
\hline 1 & Enzymun-Test ${ }^{\circledR}$ & RIA, method 1 & 73 & 0.842 & -0.356 & 3.11 & 2.34 & 0.953 \\
\hline 3 & Enzymun-Test ${ }^{\circledR}$ & EIA MAK, method 3 & 74 & 0.981 & 0.015 & 37.4 & 35.6 & 0.981 \\
\hline 4 & Enzymun-Test ${ }^{\circledR}$ & EIA MAK, method 3 & 58 & 1.091 & -1.176 & 14.5 & 14.5 & 0.979 \\
\hline 5 & Enzymun-Test ${ }^{\circledR}$ & EIA MAK, method 3 & 96 & 0.988 & -0.650 & 326 & 320 & 0.995 \\
\hline 8 & Enzymun-Test ${ }^{\circledR}$ & EIA PAK, method 5 & 60 & 1.222 & 0.636 & 0.9 & 1.7 & 0.633 \\
\hline 10 . & Enzymun-Test ${ }^{\circledR}$ & EIA MAK, method 3 & 45 & 1.091 & -0.798 & 12.6 & 12.6 & 0.933 \\
\hline 13 & Enzymun-Test ${ }^{\circledR}$ & EIA MAK, method 3 & 106 & 1.043 & -0.043 & 136 & 136 & 0.998 \\
\hline 14 & Enzymun-Test ${ }^{\circledR}$ & RIA, self developed & 32 & 0.955 & -0.770 & 18.9 & 16.6 & 0.941 \\
\hline 15 & Enzymun-Test ${ }^{\circledR}$ & EIA PAK, method 5 & 149 & 1.008 & -0.034 & 396 & 535 & 0.997 \\
\hline 15 & Enżymun-Test ${ }^{\circledR}$ & EIA PAK, method 2 & 116 & 1.004 & 0.693 & 5.84 & 6.61 & 0.998 \\
\hline
\end{tabular}




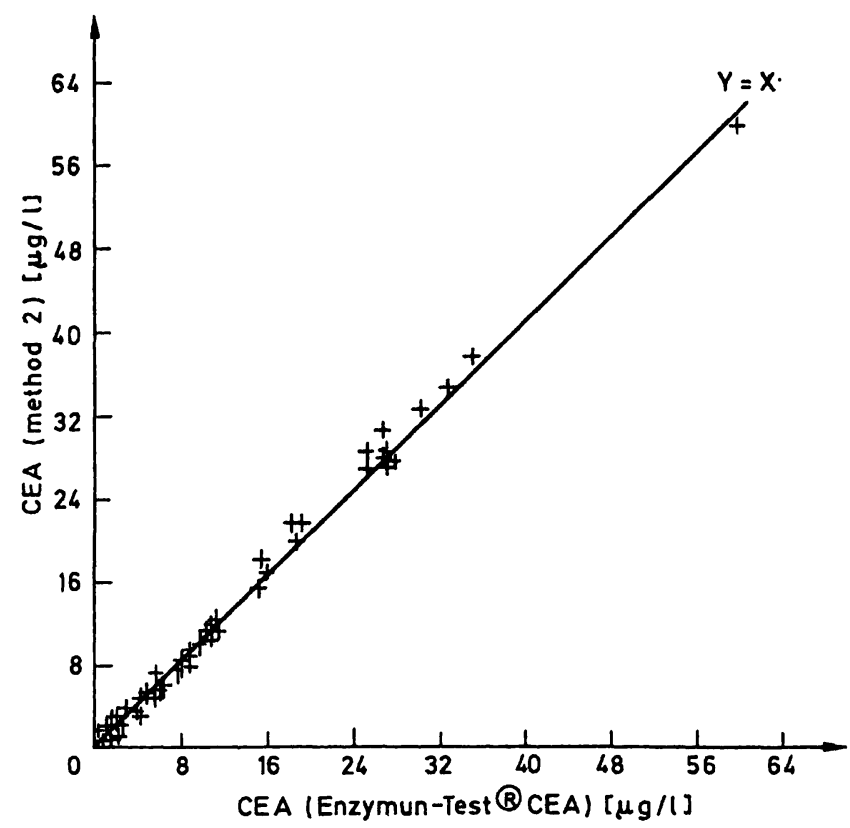

Fig. 4. Method comparison, CEA method 2.0-64 $\mu \mathrm{g} / \mathrm{l} \mathrm{CEA}$, total results, $\mathrm{N}=116$

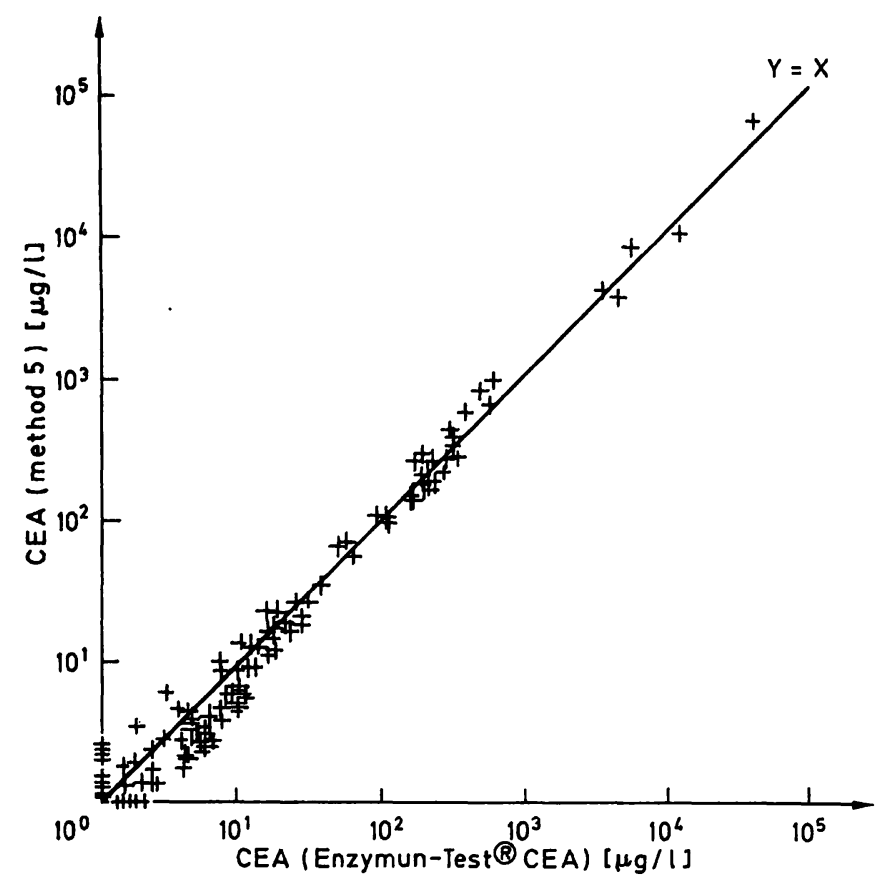

Fig. 5. Method comparison, CEA method 5.0-56000 $\mu \mathrm{g} / 1$ CEA, total results, $\mathrm{N}=149$.

Tab. 4. Distribution of CEA values in healthy subjects.

\begin{tabular}{|c|c|c|c|c|c|c|}
\hline & $\mathbf{N}$ & $\begin{array}{l}\text { Min. } \\
{[\mu g / 1]}\end{array}$ & $\begin{array}{l}5^{\text {th }} \text { Percentile } \\
{[\mu \mathrm{g} / 1]}\end{array}$ & $\begin{array}{l}\text { Median } \\
{[\mu \mathrm{g} / \mathrm{l}]}\end{array}$ & $\begin{array}{l}\text { 95th Percentile } \\
{[\mu \mathrm{g} / \mathrm{l}]}\end{array}$ & $\begin{array}{l}\text { Max. } \\
{[\mu \mathrm{g} / 1]}\end{array}$ \\
\hline \multicolumn{7}{|l|}{ Healthy subjects } \\
\hline $\begin{array}{l}\text { Total }^{1} \text { ) } \\
\text { Men } \\
\text { Women }\end{array}$ & $\begin{array}{l}541 \\
180 \\
218\end{array}$ & $\begin{array}{l}0 \\
0 \\
0\end{array}$ & $\begin{array}{l}0.1 \\
0.1 \\
0\end{array}$ & $\begin{array}{l}1.5 \\
1.7 \\
1.1\end{array}$ & $\begin{array}{l}4.9 \\
6.1 \\
4.0\end{array}$ & $\begin{array}{r}10.5 \\
8.2 \\
5.0\end{array}$ \\
\hline $\begin{array}{l}\text { Non-smokers, total } \\
\text { Men } \\
\text { Women }\end{array}$ & $\begin{array}{r}137 \\
38 \\
36\end{array}$ & $\begin{array}{l}0.2 \\
0.6 \\
0.2\end{array}$ & $\begin{array}{l}0.6 \\
0.7 \\
0.7\end{array}$ & $\begin{array}{l}1.5 \\
1.9 \\
1.2\end{array}$ & $\begin{array}{l}3.6 \\
4.5 \\
3.2\end{array}$ & $\begin{array}{l}4.6 \\
4.6 \\
3.6\end{array}$ \\
\hline $\begin{array}{l}\text { Smokers, total } \\
\text { Men } \\
\text { Women }\end{array}$ & $\begin{array}{r}171 \\
18 \\
21\end{array}$ & $\begin{array}{l}0.3 \\
0.8 \\
0.3\end{array}$ & $\begin{array}{l}0.8 \\
1.0 \\
0.6\end{array}$ & $\begin{array}{l}2.3 \\
2.1 \\
1.7\end{array}$ & $\begin{array}{l}8.2 \\
7.1 \\
4.4\end{array}$ & $\begin{array}{r}10.5 \\
8.2 \\
4.9\end{array}$ \\
\hline
\end{tabular}

1) Only part of the total number was differentiated in men, women, non-smokers and smokers.

Tab. 5. Distribution of CEA values in patients with malignant and non-malignant diseases.

\begin{tabular}{|c|c|c|c|c|c|c|}
\hline & $\mathbf{N}$ & $\begin{array}{l}\text { Min. } \\
{[\mu \mathrm{g} / 1]}\end{array}$ & $\begin{array}{l}5^{\text {th }} \text { Percentile } \\
{[\mu \mathrm{g} / 1]}\end{array}$ & $\begin{array}{l}\text { Median } \\
{[\mu \mathrm{g} / 1]}\end{array}$ & $\begin{array}{l}95^{\text {th }} \text { Percentile } \\
{[\mu \mathrm{g} / \mathrm{l}]}\end{array}$ & $\begin{array}{l}\operatorname{Max} . \\
{[\mu \mathrm{g} / \mathrm{l}]}\end{array}$ \\
\hline \multicolumn{7}{|l|}{ Carcinoma } \\
\hline $\begin{array}{l}\text { Colorectal } \\
\text { Mammary } \\
\text { Pulmonary } \\
\text { Ovarian/Cervix } \\
\text { Medullary thyroid } \\
\text { Thyroid } \\
\text { Bladder }\end{array}$ & $\begin{array}{r}61 \\
168 \\
36 \\
34 \\
17 \\
74 \\
200\end{array}$ & $\begin{array}{l}0.8 \\
0 \\
0.1 \\
0 \\
0.1 \\
0 \\
0.3\end{array}$ & $\begin{array}{l}0.8 \\
0 \\
0.2 \\
0.2 \\
0.2 \\
0 \\
0.3\end{array}$ & $\begin{array}{r}70.0 \\
2.2 \\
8.9 \\
1.9 \\
22.9 \\
0.1 \\
1.7\end{array}$ & $\begin{array}{r}5425.0 \\
381.0 \\
1634.5 \\
20.0 \\
1741.5 \\
4.9 \\
8.1\end{array}$ & $\begin{array}{r}11180.0 \\
1500.0 \\
2250.0 \\
32.3 \\
3100.0 \\
7.8 \\
12.1\end{array}$ \\
\hline \multicolumn{7}{|l|}{ Non-malignant disease } \\
\hline $\begin{array}{l}\text { Pancreatic } \\
\text { Hepatic/Cirrhosis } \\
\text { Dialysis } \\
\text { Other }\end{array}$ & $\begin{array}{l}14 \\
27 \\
59 \\
46\end{array}$ & $\begin{array}{l}0.4 \\
0 \\
0 \\
0\end{array}$ & $\begin{array}{l}0.5 \\
0.3 \\
0.1 \\
0.2\end{array}$ & $\begin{array}{l}1.4 \\
1.9 \\
2.4 \\
2.5\end{array}$ & $\begin{array}{l}4.3 \\
6.4 \\
7.8 \\
8.9\end{array}$ & $\begin{array}{r}5.3 \\
6.9 \\
10.2 \\
11.1\end{array}$ \\
\hline
\end{tabular}


tumour classification or therapy was recorded for the carcinoma patients. In healthy subjects a median of $1.5 \mu \mathrm{g} / \mathrm{l}$ CEA with $95 \%$ of all values between $0-4.9$ $\mu \mathrm{g} / \mathrm{l}$ CEA was recorded. The median of $2.3 \mu \mathrm{g} / \mathrm{l}$ CEA for smokers was significantly higher (U-test, MannWhitney) than the median of $1.5 \mu \mathrm{g} / \mathrm{l}$ CEA for nonsmokers. Higher CEA values were found in men than in women. CEA levels were elevated in colorectal, mammary, pulmonary, medullary and thyroid carcinoma. Slightly elevated values were observed in patients with ovarian and cervical carcinoma. CEA was not elevated in patients with thyroid or bladder cancers. In the group of non-malignant patients CEA values ranges from $4.3-8.9 \mu \mathrm{g} / \mathrm{l}$ ( $95 \%$ of all values).

\section{Follow-up studies}

In retrospective follow-up studies, time courses showing both increasing and decreasing CEA concentrations in patients with colon carcinoma were determined with Enzymun-Test ${ }^{\circledR}$ CEA and the routine assay (figs. 6, 7). A good correlation was found.

\section{Discussion}

The data of the present study indicate that CEA serum levels determined with the new EIA exhibit a high degree of correlation with other enzyme immunoassay or radioimmunoassay systems. Some previous studies showed a good correlation between different assay methods $(8,9,10)$, whereas other

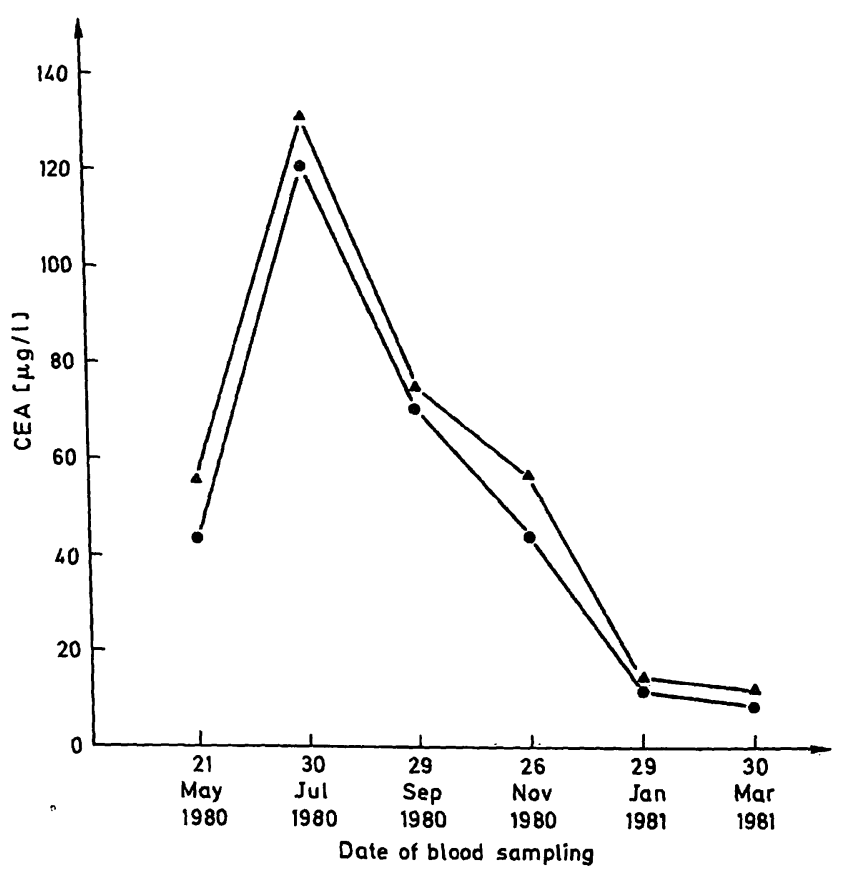

Fig. 6. Follow-up study of a patient with colon carcinoma. $\triangle$ Enzymun-Test ${ }^{\circledR}$ CEA, o CEA, method 3. investigations $(11,12)$ showed a low degree of correlation or even lack of comparability. The poor correlation reported previously is partly due to the partial structural similarity of CEA with non-specific crossreaction antigen (NCA) and biliary glycoprotein (BGP). The good correlation of the present assay system with other methods suggests that patients do not have to be monitored by the same laboratory. This result is of interest for the treatment of patients. In addition, a good specificity of the present CEA EIA system was noted. It was found that the asssay was not influenced by icteric, haemolytic and lipaemic serum conditions. Furthermore, drugs used for the therapy of cancer patients did not affect the reproducibility or accuracy of the assay. The multi-centre structure of this investigation also revealed the great specificity of the present assay system, as shown by CEA data obtained from normal subjects and from patients with non-malignant diseases. A total of $95 \%$ of all CEA levels recorded in serum of 541 normal subjects were found to be between zero and $4.9 \mu \mathrm{g} / \mathrm{l}$. A median of all values was determined at $1.5 \mu \mathrm{g} / 1$ CEA. In smokers the median was $2.3 \mu \mathrm{g} / \mathrm{l}$, significantly higher than in non-smokers $(1.5 \mu \mathrm{g} / 1$ CEA $)$. But a cross-over of CEA concentrations is found between acute benign diseases and early tumour stages, as already well documented for other CEA assay methods. The differentiation between benign diseases and late tumour stages is clinically not important. It was interesting to note that CEA levels were higher in males than in females. No explanation can be given for this at present.

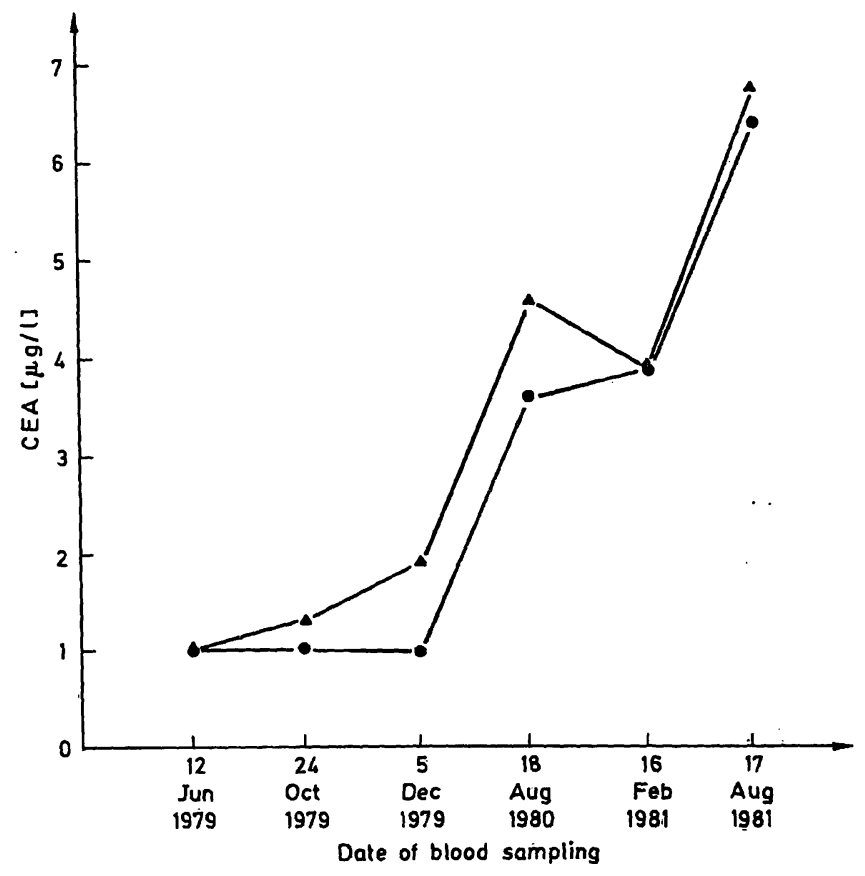

Fig. 7. Follow-up study of a patient with colon carcinoma. $\triangle$ Enzymun-Test CEA, CEA, method 3. $\because$

J. Clin. Chem. Clin. Biochem. / Vol. 25, 1987 / No. 1 
Present data combine to suggest that this new CEA EIA system, utilizing monoclonal antibodies, is a valuable diagnostic tool. This multi-centre study has shown that this assay system exhibits a high degree of sensitivity, specificity and reproducibility. The high degree of correlation with other assay systems permits the comparison of data obtained by various other methods with this new CEA EIA.

\section{References}

1. Neville, A. M. \& D. J. R. (1974) Int. J. Cancer 14, 1-18.

2. Rasmuson, T., Björk, G. R., Damber, Holm, S. E., Jakobsson, L., Jeppson, A., Stigbrand, T. \& Westman, G. (1984) Acta Radiol. Oncol. 23, 27-32.

3. Fritsche, H. A. (1984) Clin. Chem. News 10, 14-16.

4. Heim, E. B., Sauer, G., Schnitzler, G., Haux, P. \& Feldmann, U. 1984) TumorDiagnostik \& Therapie 5, 220-224.

5. Lahousen, M., Stettner, H., Pickel, H., Pürstner, P. \& Urdl, W. (1984) TumorDiagnostik \& Therapie 5, 229-233.

6. Ockhuizen, Th., de Bruijn, H. W. A., Schilthuis, M. S., Szabo, B. G. \& Aalders, J. G. (1984) TumorDiagnostik \& Therapie 5, 225-228.

7. Lamerz, R. \& Fateh-Moghadam, A. (1975) Klin. Wochenschr. 53, 193-205.

8. Delacroix, D. L., Dehnnin, J. P. \& Dive, C. (1984) TumorDiagnostik \& Therapie 5, 206-210.

9. Staab, H. J., Glock, S. \& Hornung, A. (1982) TumorDiagnostik \& Therapie 3, $183-194$.

10. Tomitta, J. T., Kim, Y. D., Schenck, J. R., Przywara, L. W. \& Rose, S. P. (1984) J. Clin. Immunoassay 7, 107-111.

11. Pape, S., Neumeier, D., Kristin, H. \& Fateh-Moghadam, A. (1983) Lab. Med. 7, 3-8.
12. Davidson, H., Pledger, D. R. \& Belfield, A. (1985) Ann. Clin. Biochem. 22, 94-97.

13. Mattersberger, J., Lenz, H., Naujoks, K., Hutloff, H., Kleinhammer, G., Deeg, R. \& Linke, R. (1984) XII Int. Congr. Clin. Chem., Rio de Janeiro, abstract no. 1409.

14. Laurence, D. J. R., Tuberville, C., Anderson, S. G. \& Neville, A. U. (1975) Brit. J. Cancer 32, 295-299.

15. Krupey, J., Terrance, W., Freedman, S. O. \& Goldy, P. (1982) Immunochemistry 9, 617-622.

16. Krantz, M. J., Laferté, S. \& Ariel, N. (1982) Methods in Enzymology 84, 32-84.

17. Acolla, R. S., Carell, S. \& Mach, J. P. (1980) Proc. Natl. Acad. Sci. USA 77, 563-566.

18. Steward, M. W. \& Pettc, R. E. (1972) Immunology 23, $881-887$.

19. Kleist, Sabine von, Chavanel, G. \& Burton, P. (1972) Proc. Natl. Acad. Sci. USA 69, 2492-2494.

20. Meyer, H. D. \& Braun, S. L. (1985) Ärztl. Lab. 31, 308312.

21. Staber, G., Busch, E. W. \& Koller, P. U. (1982) Med. Lab. $35,10-13$.

22. Passing, H. \& Bablok, W. (1983) J. Clin. Chem. Clin. Biochem. 21, 709-720.

Prof. Dr. J. Spona

I. Universitäts-Frauenklinik

Spitalgasse 23

A-1090 Wien 